\title{
PENTINGNYA PENGENALAN VAKSIN DI MASA PANDEMI COVID-19 DESA IBUL KECAMATAN SIMPANG TERITIP
}

\author{
Andriadi $^{1}$, Bella Putri Agustiarasari ${ }^{2}$, Dianto ${ }^{3}$, Dila Monica ${ }^{4}$, Muhammad Jordan ${ }^{5}$, Muhammad \\ Risky $^{6}$, Poppy Arsika ${ }^{7}$, Rafita Syari ${ }^{8}$, Rizki Nursapitri ${ }^{9}$, Salmawati ${ }^{10}$ \\ Fakultas Keguruan Ilmu Pendidikan \\ Universitas Muhammadiyah Bangka Belitung \\ *e-mail: $\underline{\text { Salmawati8467@gmail.com }}{ }^{1}$ dilamonicaa@gmail.com ${ }^{2}{ }_{2}$ sandisajasandi678@gmail.com ${ }^{3}$
}

\begin{abstract}
The Covid-19 pandemic has hit the world, also having a visible impact in various sectors including social, tourism and education. The Covid-19 pandemic is still hitting various regions in Indonesia. As of February 25, 2021, there were 157,859 new cases recorded so that cumulatively there were 1,314,634 cases of Covid-19. Cases recovered increased by 112,867 patients so that the total number of patients recovered was 1,121,411 people. However, the death cases increased by 6.85 people to 35,518 people. Covid-19 has hit 34 Provinces and 485 Regencies or Cities (Covid19.gold.id, 25februari2021). According to the Directorate of health surveillance and quarantine and the Directorate General of P2P of the Ministry of Health (2020) a vaccine is a (biological) compound that is given to someone with the intention of producing immunity to a disease by stimulating the production of antibodies. The speaker, Nur Azizah, S KM, with the theme "Covid-19 Immunization Policy", contains the meaning of vaccines, vaccine injection, the purpose of the covid-19 vaccine, the target of the covid-19 vaccine, the dosage and method of giving the covid-19 vaccine, and along with the flow. Covid-19 vaccination services. For now it is very important to hold socialization about the covid-19 vaccine to combat hoax news circulating at this time, so that people do not feel afraid of the covid-19 vaccine. The author conducted this research to find out what positive effects were obtained from the socialization results about the covid-19 vaccine. Socialization about the covid-19 vaccine to combat hoax news circulating at this time, so that people do not feel afraid of the covid-19 vaccine.
\end{abstract}

Keywords:introduction, vaccine, covid-19

\begin{abstract}
Abstrak
Pandemi covid-19 melanda dunia, juga memberikan dampak yang terlihat nyata dalam berbagai sektor diantaranya sosial, pariwisata, dan pendidikan. Pandemi Covid-19 masih melanda berbagai wilayah di Indonesia. Hingga 25 Februari 2021, terdata sebanyak 157.859 kasus baru sehingga secara akumulatif terdapat 1.314.634 kasus Covid-19. Kasus sembuh bertambah 112.867 pasien sehingga total pasien sembuh sebanyak 1.121 .411 orang. Namun kasus meninggal bertambah 6.85 orang menjadi 35.518 orang. Covid-19 telah melanda 34 Provinsi dan 485 Kabupaten atau Kota (Covid19.gold.id,25februari2021). Menurut Direktorat surveilans dan karantina kesehatan dan Ditjen P2P Kementrian Kesehatan (2020) vaksin merupakan suatu senyawa (biologis) yang diberikan kepada seseorang dengan maksud untuk menghasilkan kekebalan terhadap suatu penyakit dengan cara menstimulasi produksi antibody. Pemateri Nur Azizah,S KM yang bertema "Kebijakan Pemberian Imunisasi covid-19" materi tersebut berisi tentang pengertian vaksin, penyuntikan vaksin, tujuan vaksin covid-19, sasaran vaksin covid-19, dosis dan cara pemberian vaksin covid -19 , dan besrta alur pelayanan vaksinasi covid 19. Untuk saat ini sangatlah penting diadakan sosialisasi tentang vaksin covid-19 untuk memerangi berita hoax yang beredar saat ini ,agar masyarakat tidak merasa takut untuk di vaksin covid-19. Penulis melakukan penelitian ini untuk mengetahui apa saja dampak positif yang didapatkan dari hasil sosoalisasi tentang vaksin covid-19. Sosialisasi tentang vaksin covid-19 untuk memerangi berita hoax yang beredar saat ini ,agar masyarakat tidak merasa takut untuk di vaksin covid-19.
\end{abstract}

Kata kunci : Pengenalan,vaksin, covid-19 


\section{PENDAHULUAN}

Pemerintah telah menentukan Corona Virus Disease 2019 (covid-19) sebagai bencana non alam, pandemi covid-19 memberi tantangan besar dalam upaya peningkatan derajat kesehatan masyarakat di Indonesia. Pemerintah telah mengumumkan kasus konfirmasi pertama covid-19 di Indonesia pada awal Maret 2020. Dalam rentang waktu satu bulan seluruh Provinsi telah melaporkan kasus konfirmasi penyebaran covid-19 tidak hanya terjadi di daerah khusus ibukota Jakarta dan kota padat penduduk lainnya, namun telah menyebar hingga pedesaan. Pandemi covid-19 melanda dunia, juga memberikan dampak yang terlihat nyata dalam berbagai sektor diantaranya sosial, pariwisata, dan pendidikan. Pandemi Covid-19 masih melanda berbagai wilayah di Indonesia. Hingga 25 Februari 2021, terdata sebanyak 157.859 kasus baru sehingga secara akumulatif terdapat 1.314.634 kasus Covid-19. Kasus sembuh bertambah 112.867 pasien sehingga total pasien sembuh sebanyak 1.121 .411 orang. Namun kasus meninggal bertambah 6.85 orang menjadi 35.518 orang. Covid-19 telah melanda 34 Provinsi dan 485 Kabupaten atau Kota (Covid19.gold.id,25februari2021). Untuk menangani Covid-19, pemerintah membuat berbagai kebijakan guna melindungi masyarakat dari penularan dan dampak Covid-19 mulai Dari pembatasan sosial berskala besar termasuk pembatasan sekolah, tempat kerja, tempat peribadahan, tempat umum dan trasportasi; pemberian bantuan sosial; pemberian insentif bagi tenaga kesehatan; kebijakan masker untuk semua; dan kebijakan penerapan protokol kesehatan di berbagai tempat yang terus di gaungkan selagi menanti vaksin.

Pemerintah Indonesia dan juga negara-negara di dunia tengah berupaya mengembangkan dan menghadirkan vaksin covid-19 serta merencanakan pelaksanaan imunisasi untuk warganya. Indonesia selain turut mengembangkan calon vaksin yang di buat negara lain, juga mengembangkan calon vaksin dalam negeri yang di beri nama vaksin merah putih. Vaksin ini di kembangkan oleh LBM Eijkmal, BPPT, LIPI, Badan POM, Kemenristek/BRIN serta sejumlah universitas.

Penelitian, pengembangan dan produksi vaksin dalam negeri tersebut telah mendapat dukungan dari Komisi IX DPR RI melalui Rapat Kerja Bersama Kemenristek/BRIN, Kementrian Kesehatan, Badan POM serta PT Bio.Farma (Persero) Pada 14 Juli 2020. Vaksin memberikan manfaat penting kepada semua orang. Melalui vaksinisasi, kita dapat melindungi diri dari penyakit infeksi yang berbahaya bahkan penyakit mematikan. Berdasarkan WHO, pada tahun 2010-2015 setidaknya hampir 10 juta angka kematian diseluruh dunia berhasil dicegah oleh vaksinisasi. Banyak kehidupan yang dilindungi dari berbagai penyakit seperti, pneumonia, diare, batuk renjan, campak, dan polio. Vaksinisasi merupakan salah satu cara pencegahan penyakit menular yang tidak hanya diberikan kepada bayi, melainkan kepada orang dewasa juga. Adapun cara kerjanya yaitu dengan memberikan antigen bakteri atau virus tertentu yang sudah dilemahkan atau dimatikan yang kemudian merangsang sistem kekebalan tubuh untuk dapat mengetahui, menghancurkan, dan mengingat benda asing. Sehingga tubuh dapat dengan mudah mengenali dan mencegah benda asing yang nantinya masuk dan menyerang tubuh.

Banyak sekali berita negatif tentang adanya dampak Vaksin Covid-19, hampir semua masyarakat terpengaruhi dengan adanya berita negatif (Hoax) seperti, meninggalnya seseorang yang telah disuntikan Vaksin Covid-19, terjadinya kelumpuhan, kebutaan, dll.

Sehingga berita tersebut dengan cepat menyebar ke masyarakat Indonesia khususnya di wilayah Kecamatan Simpang Teritip, Desa Ibul. Sehingga, masyarakat Desa Ibul merasa takut untuk melakukan Vaksin Covid-19. Kemudian hal tersebut melatarbelakangi Mahasiswa KKN Universitas Muhammadiyah Bangka Belitung bekerja sama dengan Puskesmas Simpang Teritip melakukan sosialisasi dengan judul "Pentingnya Pengenalan 
Vaksin Di Masa Pandemi Covid-19 Desa Ibul Kecamatan Simpang Teritip". Dengan adanya penelitian dan kegiatan ini di harapkan masyarakat Desa Ibul mengetahui Pentingnya Vaksin Di Masa Pandemi Covid-19.

\section{METODE}

Penelitian ini dilakukan dengan cara mendatangi Kepala Desa Ibul untuk meminta izin melakukan Sosialisasi tentang pengenalan vaksin covid-19 di Desa lbul. penelitian ini di laukan dengan cara survey lapangan dan sosialisasi ini berkerja sama dengan Puskesmas Simpang Teritip di tujukan untuk masyarakat yang ada di Desa lbul. Dengan ini kami sebagai peneliti ingin mengetahui seberapa besar masyarakat mengetahui tentang Vaksin Covid-19.

\section{HASIL DAN PEMBAHASAN}

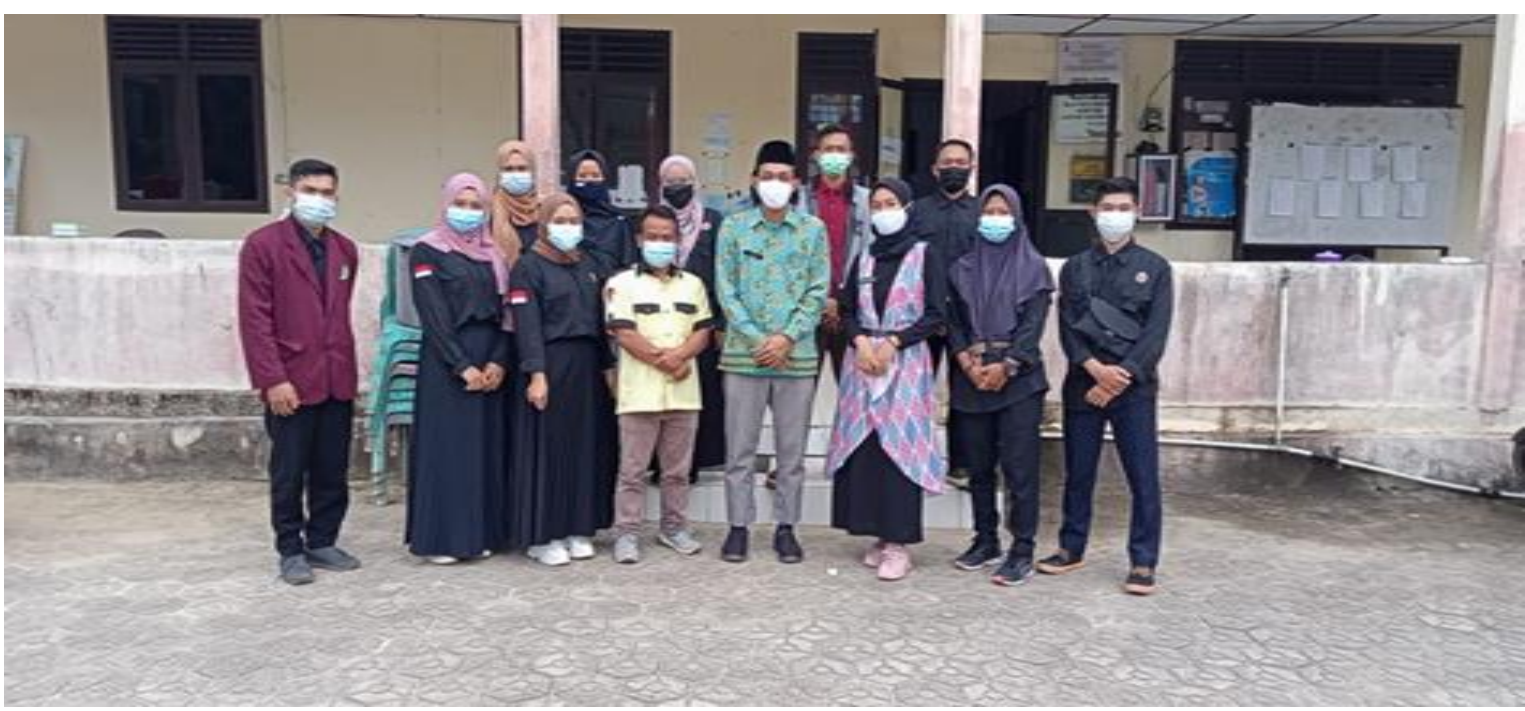

Penelitian ini dilakukan dangan cara sosialisasi sebagai himbauan ke pada masyarakat betapa pentingnya vaksin covid 19 .dan untuk masyarakat Seperti yang kita ketahui bahwa Virus Covid-19 telah memasuki Indonesia pada bulan Maret 2020. Banyak sekali usaha yang telah dilakukan pemerintah Indonesia untuk meminimalisir tingginya tingkat penyebaran virus covid-19. Covid-19 memiliki dampak yang sangat besar bagi masyarakat Indonesia sendiri. Dampak yang paling dirasakan adalah pada ekonomi dikarenakan banyaknya pengurangan pegawai (PHK) pada perusahaan-perusahaan industri Indonesia.

Salah satu usaha pemerintah untuk menghilangkan virus covid-19 ialah dengan cara mengekspor vaksin covid-19 dari cina langsung. Menurut pusat pendidikan dan pelatihan tenaga kesehatan (2015:8) Vaksin adalah antigen berupa mikroorganisme yang sudah mati, masih hidup tapi dilemahkan, masih utuh atau bagiannya, yang telah diolah, berupa toksin mikroorganisme yang telah diolah menjadi toksoid, protein rekombinan yang apabila diberikan kepada seseorang akan menimbulkan kekebalan spesifik secara aktif terhadap penyakit infeksi tertentu.

Menurut Direktorat surveilans dan karantina kesehatan dan Ditjen P2P Kementrian Kesehatan (2020) vaksin merupakan suatu senyawa (biologis) yang diberikan kepada seseorang dengan maksud untuk menghasilkan kekebalan terhadap suatu penyakit dengan cara menstimulasi produksi antibody. Umumnya vaksin mengandung suatu zat yang 
mewakili kuman penyebab penyakit, seringkali dibuat dari kuman yang dimatikan atau dilemahkan. Zat tersebut menstimulasi sistem kekebalan tubuh untuk mengenalinya sebagai zat asing, lalu terpincu untuk mengeliminasikannya, dan membentuk memori, sehingga sistem kekebalan tubuh dapat dengan mudah menangkal kuman jika suatu saat dikemudian hari kuman tersebut menginfeksi tubuh.

Vaksin adalah produk biologi yang berisi antigen yang bila diberikan kepada seseorang akan menimbulkan kekebelan spesifik secara aktif terhadap penyakit tertentu (www.covid19.go.id Januari 2020).

Menurut hasil penelitian Mahasiswa KKN Universitas Muhammadiyah Bangka Belitung melaksanakan Sosialisasi Pengenalan Vaksin Covid-19 Di Desa Ibul, bekerja sama dengan puskesmas Simpang Teritip, Kabupaten Bangka Barat. Pada hari Kamis, 11 Febuari 2021 di gedung serbaguna Desa Ibul. Acara tersebut dimulai pada Pukul 08:30 WIB s/d selesai. Diselenggarakan oleh mahasiswa KKN UNMUH BABEL dalam bentuk kepedulian terhadap masyarakat dan pentingnya vaksinasi.

Dalam sosialisasi pengenalan vaksin covid-19 sangatlah penting dalam melawan berita hoax yang beredar dimasyarakat saat ini tentang vaksin covid-19,dengan adanya sosialisai tersebut sangat membantu tenaga medis jika suatu saat akan dilaksananan vaksinasi kepada masyarakat.

Pada acara tersbut disampaikan oleh pemateri Nur Azizah,S KM yang bertema "Kebijakan Pemberian Imunisasi covid-19" materi tersebut berisi tentang pengertian vaksin, penyuntikan vaksin, tujuan vaksin covid-19, sasaran vaksin covid-19, dosis dan cara pemberian vaksin covid -19 , dan besrta alur pelayanan vaksinasi covid 19. Untuk saat ini sangatlah penting diadakan sosialisasi tentang vaksin covid-19 untuk memerangi berita hoax yang beredar saat ini ,agar masyarakat tidak merasa takut untuk di vaksin covid-19.

\section{KESIMPULAN}

Covid adalah sebuah wabah penyakit yang sangat berbahaya bagi seluruh dunia bahkan sangat merugikan bagal perekonomian terutama bagai Negara kita yaitu Indonesia. Karna hal tersebut dengan adanya upaya pemberhentian akan virus covid 19 pemerintah memberikan solusi dngan memberikan vaksin bagi mayarakat yang bertujuan untuk memutuskan penularan covid-19 . Dengan diadakan sosialisasi kepada masyarat tentang pengenalan vaksin bertujuan betapa pentingnya vaksin,dan menepis adanya berita -berita hoax tentang vaksin.

\section{UCAPAN TERIMA KASIH}

Penelitian yang besar umumnya tidak hanya melibatkan satu dua orang saja. Dari pihak kampus Universitas Muhammadiyah Bangka Belitung yang telah menyelenggarakan kuliah kerja nyata (KKN), Dosen Pembimbing Lapangan, pihak puskesmas Simpang Teritip, Masyarakat Desa Ibul, serta teman-teman Tim KKN di Desa Ibul dan tidak lupa juga kami ucapan kepada Jurnal Abdimas Bina Bangka yang telah membantu menerbitkan jurnal tentang Pentingnya Pengenalan Vaksin Di Masa Pandemi Covid-19 Desa Ibul Kecamatan Simpang Teritip. Kami ucapakan terimakasih banyak atas kerjasama dalam menyelesaikan peneltian ini. 


\section{DAFTAR PUSTAKA}

Ardiansyah. (2020). BIMBINGAN PENYUSUNAN LAPORAN KEUANGAN YAYASAN DARUL FALAH BERDASARKAN STANDAR AKUNTANSI KEUANGAN. Jurnal Abdimas Bina Bangsa, 1(2), 194-204. doi:10.46306/jabb.v1i2.27

Bagio, \& Teuku Athaillah. (2020). PEMBUKUAN USAHA TANI PADI DI DESA LEUHAN KECAMATAN JOHAN PAHLAWAN KABUPATEN ACEH BARAT. Jurnal Abdimas Bina Bangsa, 1(1), 80-86. doi:10.46306/jabb.v1i1.13

Buku Saku \#Infovaksin, Komite Penanganan COVID-19 dan Pemulihan Ekonomi Nasional, Satgas Penanganan COVID-19

Direktorat Surveilans Dan Karantina Kesehatan.2021. Kebijakan Pemberian Imunisasi Covid19.

Ifat Hanifah. (2020). ANALISI SURGENSI PERPPU NOMOR 1 TAHUN 2107 TENTANG AKSES INFORMASI KEUANGAN UNTUK KEPENTINGAN PERPAJAKAN. Jurnal Abdimas Bina Bangsa, 1(1), 15-25. doi:10.46306/jabb.v1i1.10

Kementrian Kesehatan RI.2014.Buku Ajar Imunisasi.Jakarta Selatan.

Prasadi, O., Nurlinda Ayu Triwuri, Dwi Novia Prasetyanti, Eka Dyah Puspita Sari, \& Agus Santoso. (2020). PENERAPAN STANDAR CARA PRODUKSI PANGAN OLAHAN YANG BAIK (CPPOB) DI CILACAP. Jurnal Abdimas Bina Bangsa, 1(2), 215-222. doi:10.46306/jabb.v1i2.29 